\title{
ANACAMPTODON SPLACHNOIDES (AMBLYSTEGIACEAE): HUNGARIAN POPULATIONS OF A MOSS SPECIES WITH A PECULIAR HABITAT
}

\author{
Csaba Németh ${ }^{1 *}$ and Peter ErzbergeR ${ }^{2}$ \\ ${ }^{1}$ Department of Botany and Soroksár Botanical Garden, Faculty of Horticultural Science, Corvinus \\ University of Budapest, H-1118 Budapest, Ménesi út 44, Hungary; *nemetcsaba@gmail.com \\ ${ }^{2}$ Belziger Str. 37, D-10823 Berlin, Germany
}

Németh, Cs. \& Erzberger, P. (2015): Anacamptodon splachnoides (Amblystegiaceae): Hungarian populations of a moss species with a peculiar habitat. - Studia bot. hung. 46(1): 61-75.

\begin{abstract}
Twenty-seven colonies of Anacamptodon splachnoides, a rare and endangered species throughout its distributional range, and protected by law in Hungary, were discovered in the Transdanubian Mountain Range, Balaton Uplands, Vértes and Gerecse Mts, as well as in the North Hungarian Mountains, Börzsöny Mts. They grow in decaying hollows of Quercus cerris filled with rain water (dendrotelma) or in wet holes without standing water. The sites are enumerated, the size of populations is estimated, and distribution maps, illustrations and a short description of the species are provided.
\end{abstract}

Key words: Anacamptodon splachnoides, dendrotelma, knot-hole moss, Quercus cerris, wet tree cavity

\section{INTRODUCTION}

Some groups of mosses have very special habitats, since they require as substrate nitrogen rich organic matter in some state of decay. The alpine endemic Tayloria rudolphiana (Garov.) Bruch et Schimp., a member of the Splachnaceae family, lives as an epiphytic species nearly exclusively on Acer pseudoplatanus L., where the remains of bird droppings accumulate in branch forks (Martiny and Urmi in ECCB 1995, KieBACHER et al. 2012). Zygodon forsteri (Dicks.) Mitt., a member of the Orthotrichaceae family, grows mainly around knotholes and similar hollows of Fagus sylvatica L., often on the callus tissue of old wounds, where water enriched with organic matter from the damaged tree runs down on the bark (Martiny and Stewart in ECCB 1995, ATHERTON et al. 2010). The European species of Leptodontium in the family Pottiaceae are found on old thatched roofs (L. flexifolium (Dicks.) Hampe, L. gemmascens (Mitt.) Braithw.) or on decaying grass matter (Blockeel in BLOCKEEL et al. 2014, MeINUNGer and SCHRÖDER 2007), whilst the alpine L. styriacum (Jur.) Limpr. grows above $2000 \mathrm{~m}$ altitude on decaying grass tussocks over sunny siliceous rocks, on rotten wood of shingle roofs, or in humus-filled crevices of mica-schists (GRIMS 1999, AMANN 1912, 
Frey et al. 2006, and own observations). In the family Amblystegiaceae the species Amblystegium radicale (P. Beauv.) Schimp. is also confined to decaying vegetation in moist habitats, mainly on the remains of Phragmites, Juncus, and Molinia, whereas in the same family Anacamptodon splachnoides (Froel. ex Brid.) Brid. inhabits wet knotholes (dendrotelmata), and moist decomposing tree bark. Among the species mentioned above, only the latter two occur in Hungary, and both are rare (Boros 1968, PAPP et al. 2010).

All across Europe, Anacamptodon splachnoides is rare and threatened (France, Italy, Austria, Czech Republic, Germany, Poland, Slovakia, Switzerland, Hungary, Romania, Serbia, Slovenia, Ukraine); according to DÜLL (1985) it is part of the subMediterranean-suboceanic-montane element. In the Red data book of European bryophytes (ECCB 1995), A. splachnoides is classified as endangered (EN), but also in all of the national Red Lists it is assigned a threatened status (LuDwig et al. 1996, KUČERA et al. 2012, SCHNYDER et al. 2004, ŞTEFĂNUȚ and GOIA 2012). In Hungary the species is also red-listed, in the EN category, and is also protected by law with an ideal value of 5000 HUF (ANON. 2012). Outside Europe it is found in North America (MAjesty K 2002) and the Caucasus (CZernyadjeVA 2007).

The genus Anacamptodon was described by BRIDEL (1819) and placed in the family Fabroniaceae, but according to molecular phylogenetic results, it is now ascribed to Amblystegiaceae (GofFINET and BUCK 2004).

The rarity of $A$. splachnoides can in part be attributed to its special microhabitat, which is not very stable over time. We find its turfs, usually of small extension, mainly and characteristically in knotholes (dendrotelmata) filled with rain water and enriched with organic matter from the slow decay of the wood as well as decomposing tree leaves falling into the pool, around moist hollows, bark wounds, and at the fork of tree trunks in moist bark fissures. Most European populations are found on Fagus sylvatica (BEDNAREK-OChyra et al. 1994, SANDron and HugonNot 2012, PLÁŠEK 2012), but other tree species with acidic bark are also reported as host trees, e.g. Carpinus betulus L., Picea abies (L.) H. Karst., Abies alba Mill, Quercus and Betula spp. (AHRENs 2001). The decaying horizontal surface of tree stumps is also suitable (Ahrens 2001, Pierrot and Pierrot 1975, SCHNYder 2011, PLÁšEK 2012), in particular of spruce, where the species colonizes a ring of resin in slow decay (SCHRÖDER and MEINUNGER 1994, 2000), or the water-filled surface inside a circular callus (AHRENs 2001). In North America host trees include Acer rubrum Lam., A. saccharum Marshall, Quercus montana Willd. (DAvis and PURSELl 2007), Fagus grandifolia Ehrh., Betula spp. and Acer spp. (MAJESTYK 2002). A. splachnoides has also been reported in North America once from a rock surface (SHARP and ANDERSON 1981) and from three collections on moist basidiocarps of the common wood decay fungus Oxyporus populinus (Schumach.) Donk, which was fruiting on wounds of Acer rubrum (DAVIS and PURSELL 2007). 
Nearly all reports from Hungary are from oak (Quercus), a few on beech (Fagus sylvatica), and a single find on birch (Betula pendula Roth) (SzEPESFALvi 1938, Boros 1915-1971, specimens in BP).

The first Hungarian occurrence was found in 1871 in the Buda Mts by Lajos Simonkai (Simonkai 1879). Since then, the species has been found in several counties and regions, so far from 24 grid cells (Fig. 1) (SZEPESFALVI 1938, Boros 1968, PAPP and ERzBerger 2003, specimens in BP). From the 1960s up to the present there were only two reports; in 1978 Sándor Orbán made a collection in the Ózd Hill region, and in 2001 the second author found a small population in the Buda Mts (PApp and Erzberger 2003). On the basis of this latter find, the growth site was selected as an IBrA (Important Bryophyte Area) (PAPP 2008).

\section{MATERIAL AND METHODS}

Geographical coordinates were determined using a Garmin eTrex Legend GPS. The drawings of details of $A$. splachnoides were made by the second author from the following specimens: B-Erzberger 19015; HCsN 6085. The morphological description of the species is based on CRUM and ANDERSON (1981), AHRENS (2001), and CZERnYADJEVA (2007). The nomenclature of the bryophytes, fungi

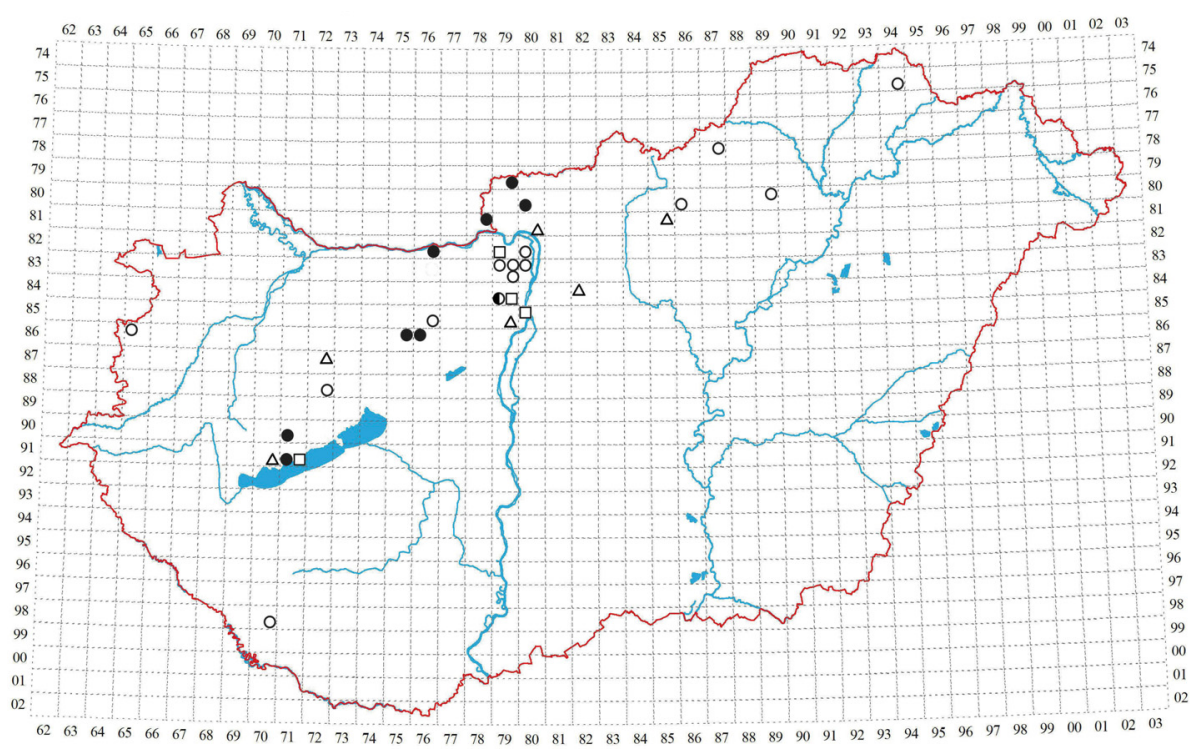

Fig. 1. Occurrences of Anacamptodon splachnoides in Hungary. (non-shaded symbols - before 1978; full shaded symbols - after 2000; half shaded symbols - observed before 1978 and after 2000 as well; circle - data supported by herbarium samples; square - literature data without herbarium vouchers; triangle - literature data with uncertain location and without herbarium voucher). 
and the vascular plants follow Hill et al. (2006), ROBERT et al. (2005) and ANON. (2010), respectively. The detailed point map is based on the bryophyte collection of the Hungarian Natural History Museum (BP) and the herbaria of the authors (B-Erzberger = herbarium of P. Erzberger, $\mathrm{HCsN}=$ herbarium of Cs. Németh).

Some occurrences cited by SzEPESFALVI (1938) cannot be attributed precisely to a given grid cell, therefore in the map these data are displayed by a separate symbol.

\section{RESULTS}

During grid cell recording of the bryophyte flora of Hungary, as well as in the framework of a research project 'Amount of dead wood and its effect on biodiversity in the Hungarian Carpathians' managed by Centre for Ecological Research (Hungarian Academy of Sciences), A. splachnoides was discovered in 8 grid cells of the Hungarian Mountain Ranges in 27 tree hollows (Table 1, Fig. 1). Of the 27 sites, 3 are situated in the Börzsöny Mts at Diósjenő, Bernecebaráti, and Letkés (Csehvár Hill, Dedre-bérc, Valley of Letkés stream), 2 in the Vértes Mts at Gánt and Csákberény (Gém Hill, Ugró Valley), 2 in the Gerecse Mts at Lábatlan (Nagy-irtás), and 20 in the Balaton Uplands. Among the latter, the site at Badacsonytomaj (Örsi Hill), with a single tree hollow occupied by Anacamtodon, is geographically disjunct from the populations at Szentbékkálla (Kopácsi Hill), where the species can be found in the hollows of 19 distinct individual trees in a 20 ha coppiced Turkey oak woodland surrounding the pond Füzes-tó, on the basaltic plateau (Fig. 2).

All populations were found in decaying, moist tree hollows or their surroundings at the stem base of Quercus cerris $\mathrm{L}$., in most cases immediately above the water level of the dendrotelma (Fig. 3), more rarely on the margins of moist hollows that lack a body of water, but where continuous seepage from the tree trunk provides the necessary moisture (Fig. 4). It should be emphasized that all Hungarian populations were found at the base of trees, at most $0.5-1 \mathrm{~m}$ above the ground, whereas reports from other countries mention their occurrence in higher parts of the tree trunk (SOLBERG 1977, CRUM and ANDERson 1981, BREIL 2003, SANDRON and HUgONNOT 2012).

The general rarity of the species is evident from the fact that in spite of the examination of several hundred seemingly appropriate dendrotelmata during the last 15 years, the species was found in only 27 tree hollows. The ratio of examined trees and populations of $A$. splachnoides found is in accord with the observations of SANDRON and HUGONNOT (2012), who examined 119 tree hollows in a beech forest of 30 ha and found the plant in 29. A similar conclusion can be drawn from the fact that Ádám Boros and László Vajda, whose field studies covered the whole country, report a total of only 15 Hungarian occurrences (Boros 1915-1971, 


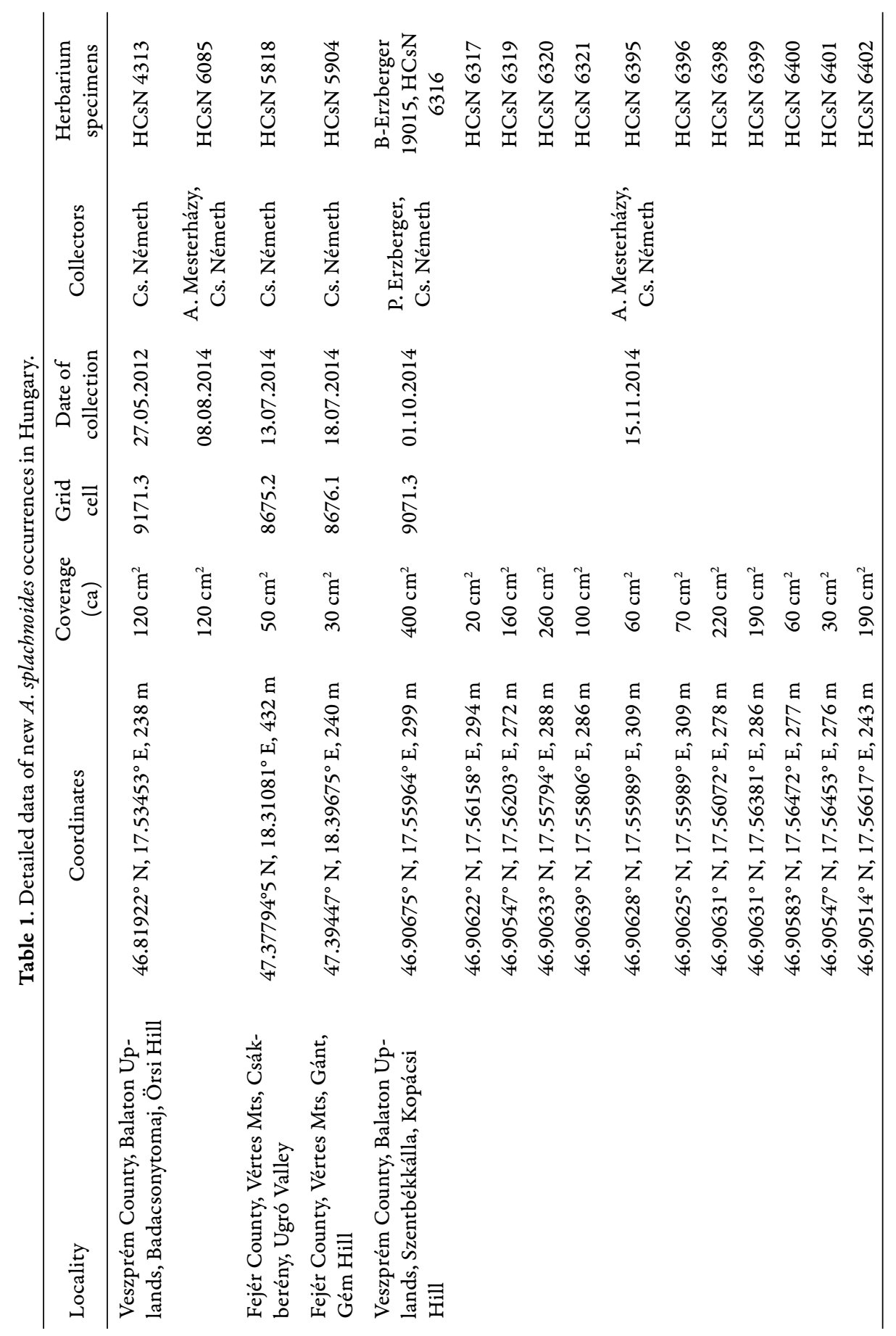

Studia bot. hung. 46(1), 2015 


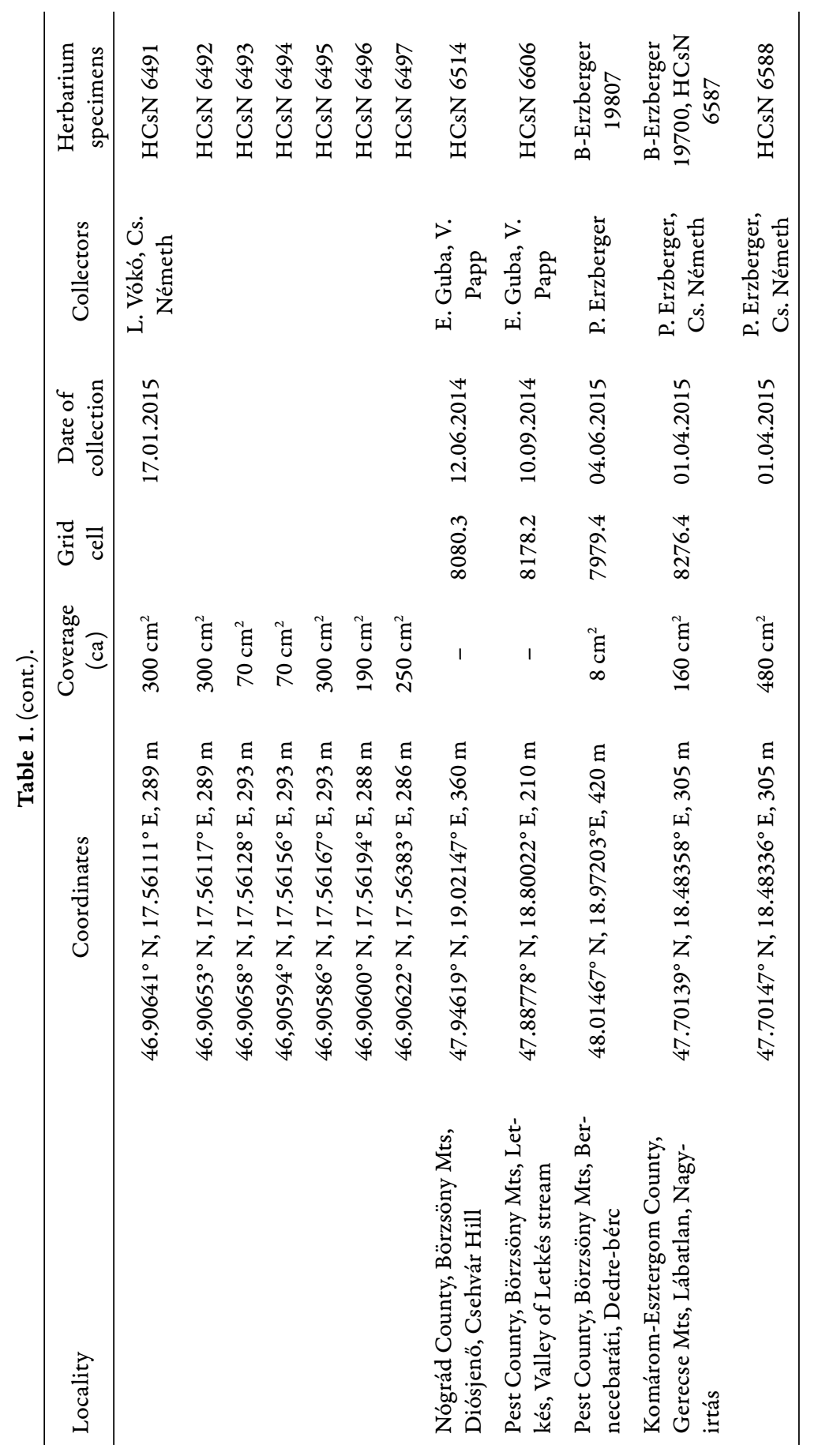

Studia bot. hung. 46(1), 2015 
Boros 1968, specimens in BP), and according to Boros's field notes there was only one site where $A$. splachnoides was found on more than one individual tree.

Our experience shows that not all kinds of tree hollows are suitable for the establishment of the species. Permanently dry hollows can be excluded a priori. Only those hollows that are filled with water for a longer or shorter period can be considered potential microhabitats, as well as bark wounds or hollows where seepage from the tree provides the necessary moisture.

Adding up the recently discovered occurrences of the species results in a total cover of $c a 4,208 \mathrm{~cm}^{2}$. Associate bryophytes are regularly Hypnum cupressiforme Hedw., more rarely Pylaisia polyantha (Hedw.) Schimp., Bryum moravicum Podp., and Amblystegium serpens (Hedw.) Schimp. In the absence of data from continuous monitoring, we know little about the development of populations in time. We can only state that the dendrotelma where the population at Örsi Hill

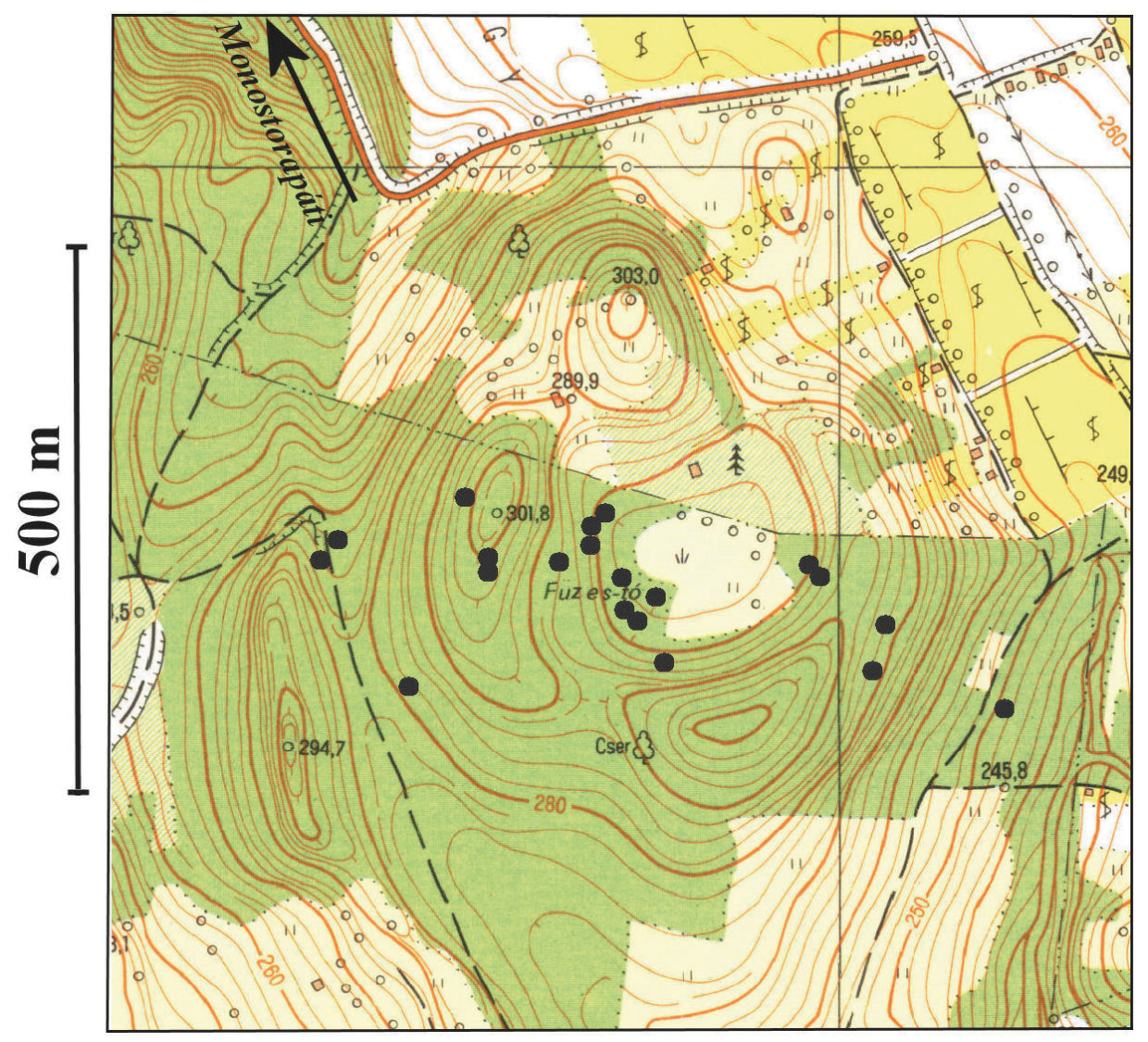

Fig. 2. Occurrences of Anacamptodon splachnoides on Kopácsi Hill near Szentbékkálla (grid cell 9071.3). 


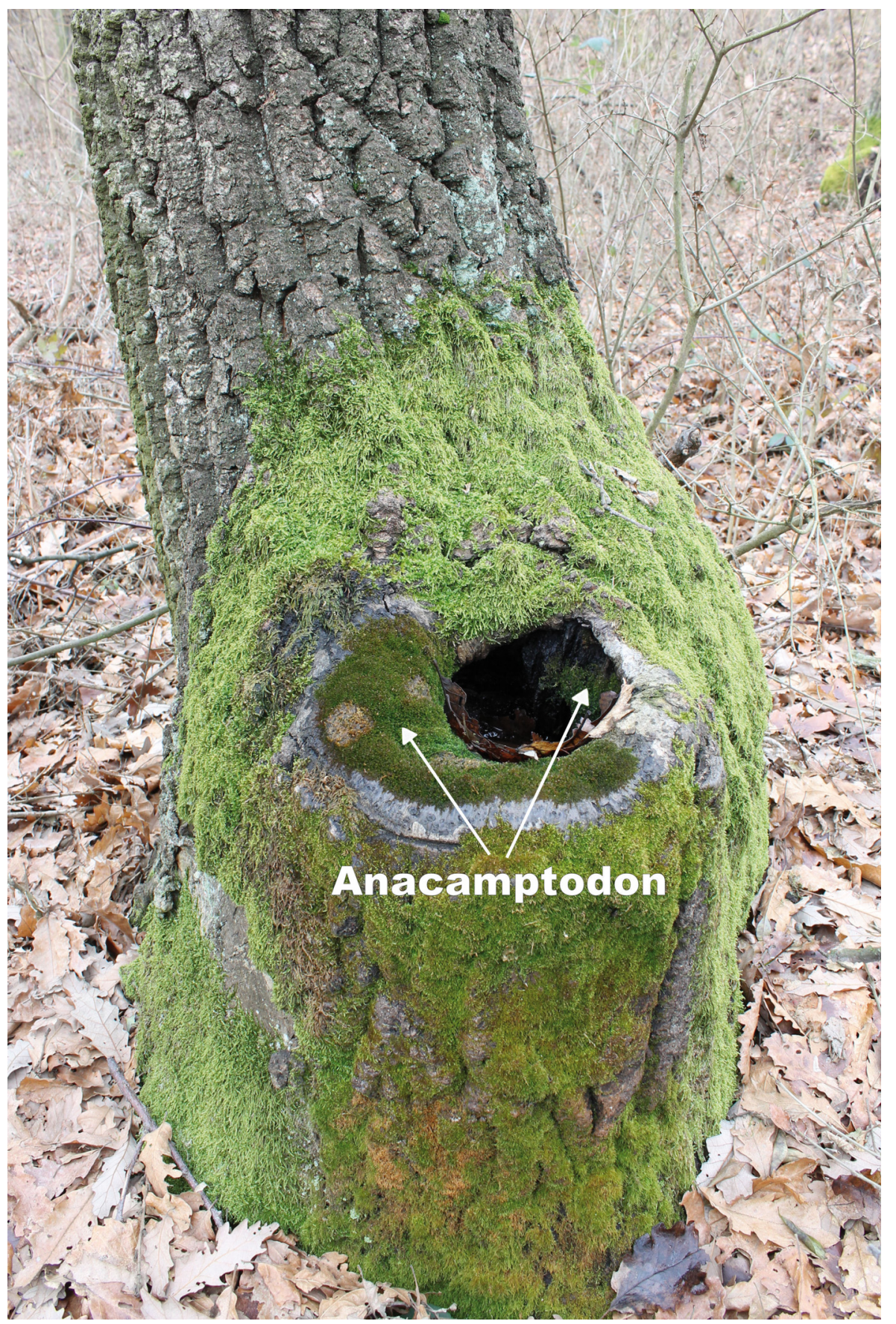

Fig. 3. Typical habitat of Anacamptodon splachnoides on Kopácsi Hill; knothole with pool. 


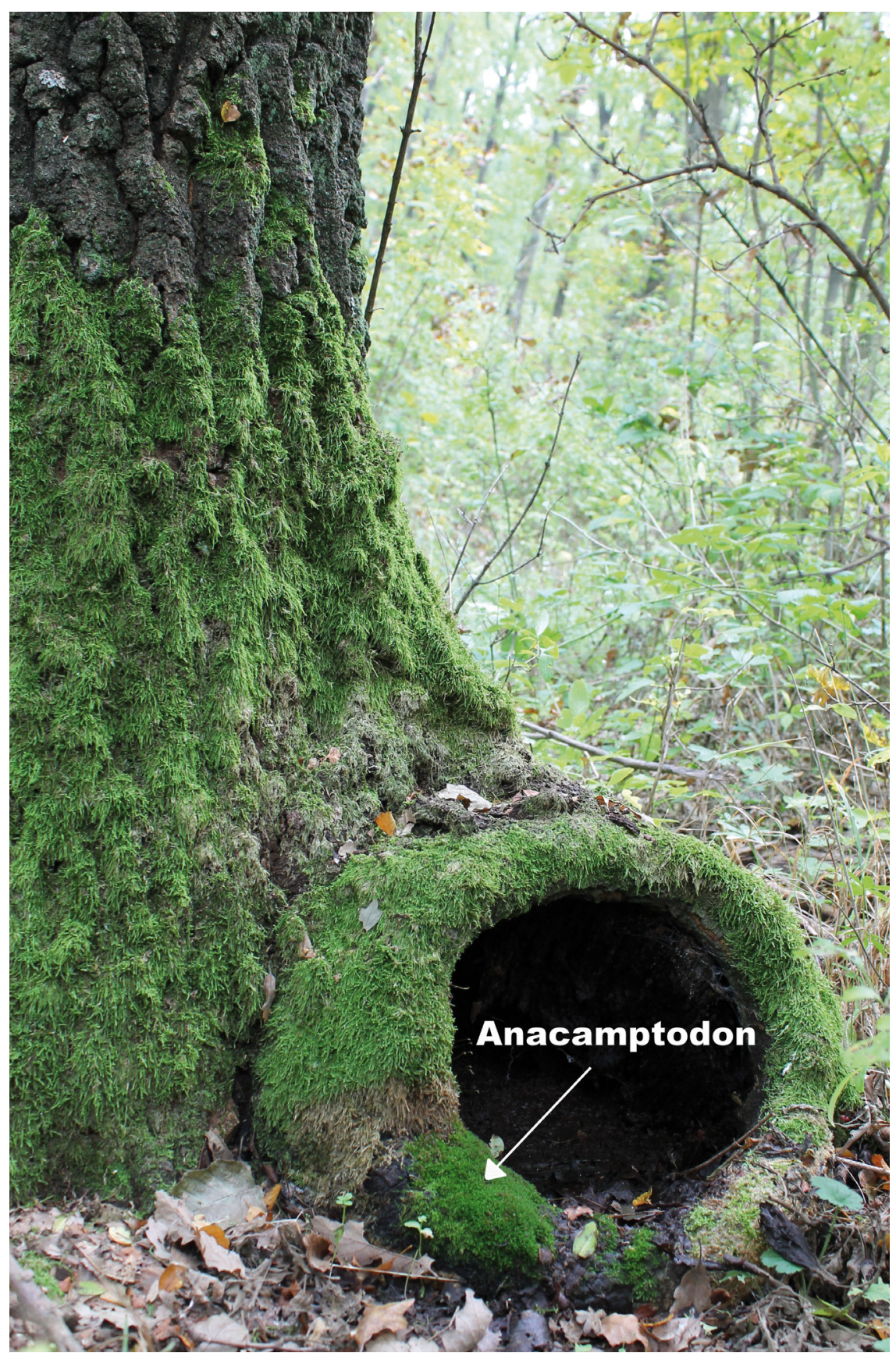

Fig. 4. Typical habitat of Anacamptodon splachnoides on Kopácsi Hill; wet knothole without dendrotelma. 
was found, was filled with water in 2012, when first noted, as well as in 2014 when checked, and the cover of the population at the edge and on the somewhat drier margin had not changed within that period.

\section{Short characterization of Anacamptodon splachnoides}

Small plants, irregularly branched, dark green prostrate shoots, densely foliated in 5 rows. Leaves ovate-lanceolate, patent when moist, erect when dry, often curved in one direction, slightly concave, gradually tapering, margins entire. The nerve reaches up to $1 / 2-2 / 3$ the leaf length. Laminal cells smooth, oblong-rhomboidal, rectangular at leaf base. Monoicous, usually producing numerous sporophytes. Capsule borne on a smooth seta, erect, symmetric, oblong-cylindric with a characteristic contraction below the orifice. Lid obliquely rostrate. Peristomium double, exostome consisting of 16 yellowish-brown, lanceolate, papillose teeth in 8 pairs, which are characteristically strongly recurved when dry; endostome consisting of 16 or 8 reddish-brown segments with smooth surface (Figs 5,6 ).

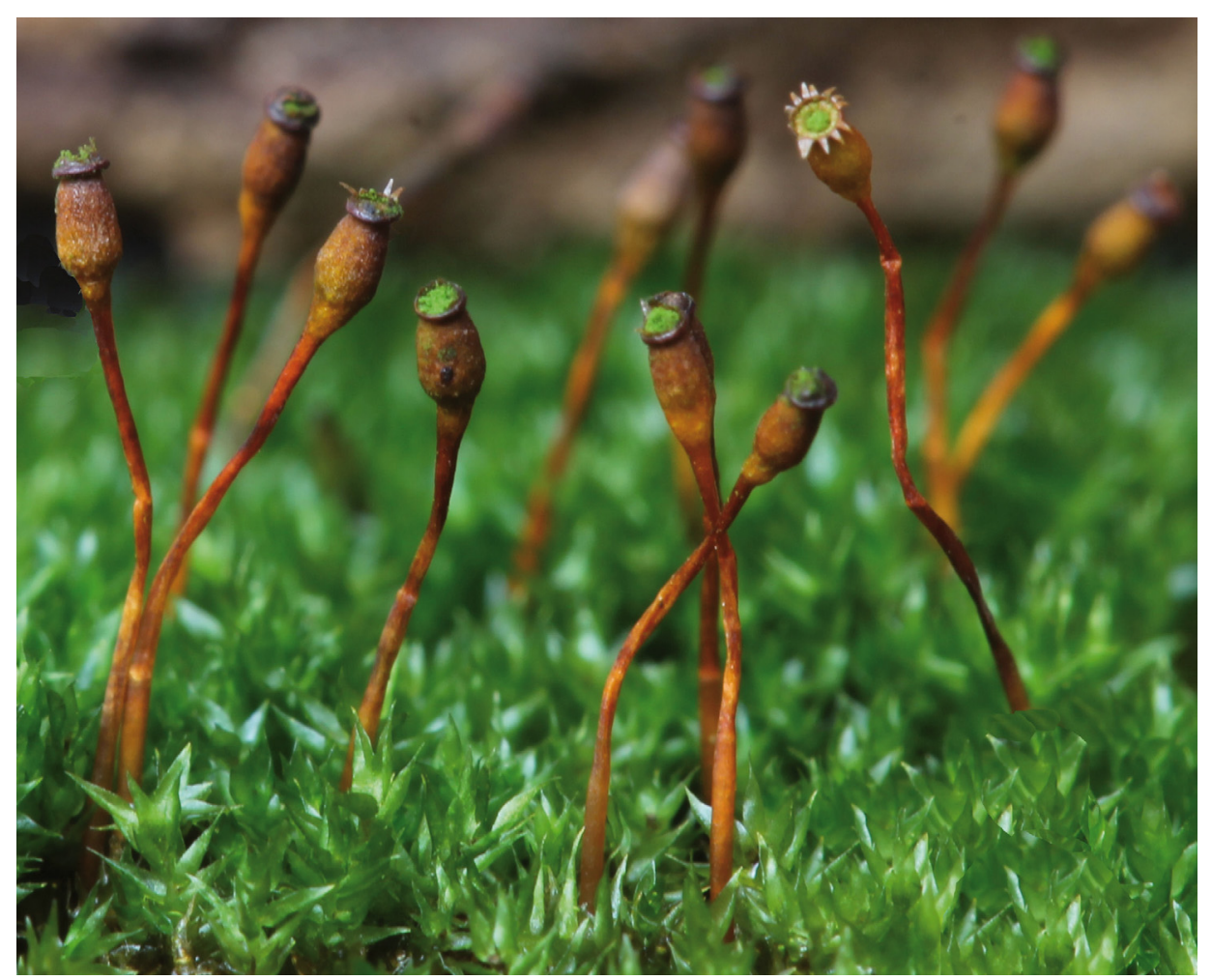

Fig. 5. Habit of Anacamptodon splachnoides. 
Characters that help identification:

- turf characteristically dark emerald green when moist

- leaf areolation clearly visible against the light with a $10 \times$ hand lens, with relatively large (ca $13 \mu \mathrm{m}$ wide and - depending on position - 30-52 $\mu \mathrm{m}$ long) cells

- capsule erect, contracted below mouth

- outer peristome teeth strongly reflexed when dry

\section{CONCLUSIONS}

Remarkably each newly discovered Hungarian population of $A$. splachnoides as well as the overwhelming majority of the earlier finds are from Quercus cerris

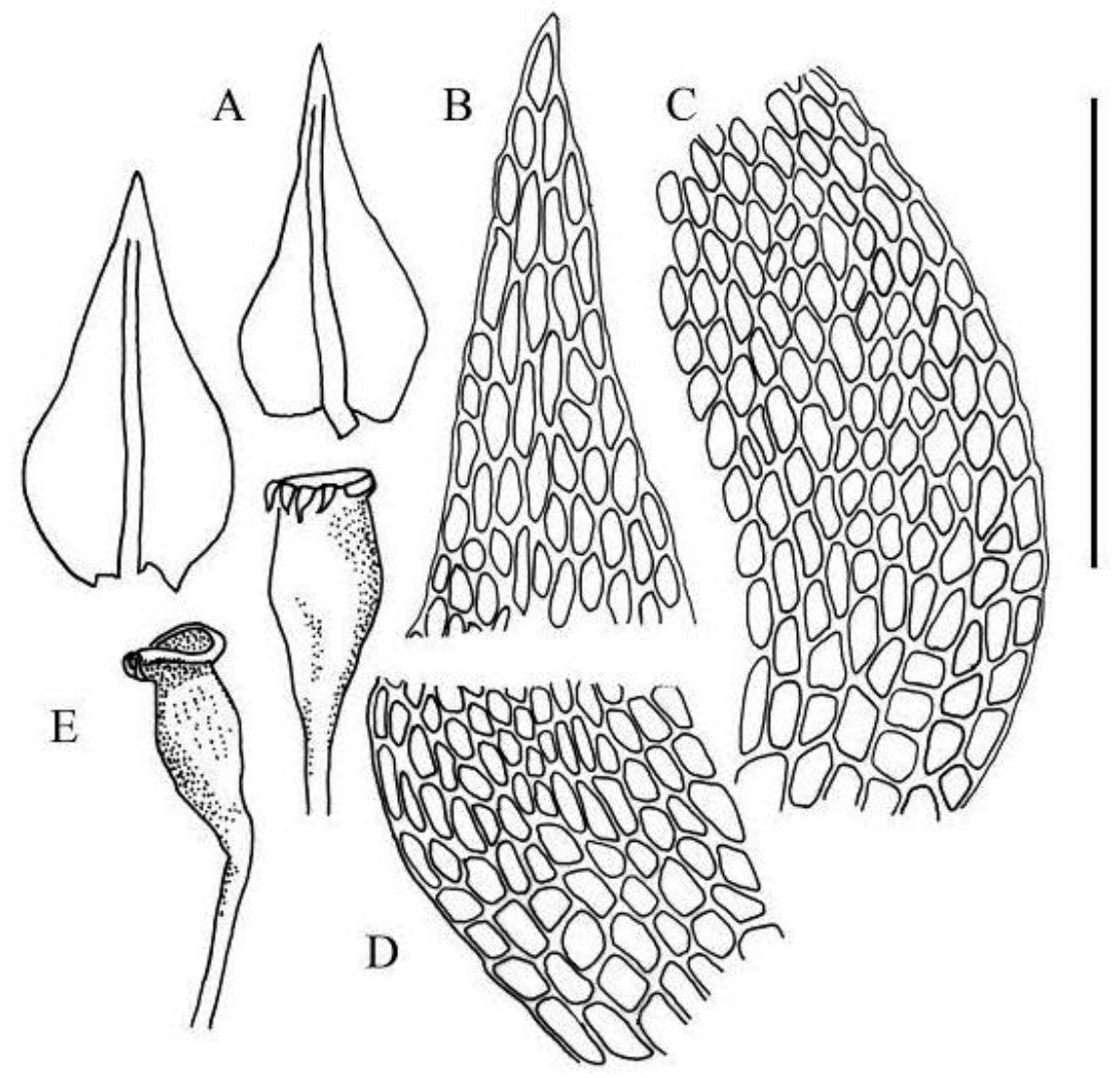

Fig. 6. Leaf and capsule of Anacamptodon splachnoides. (Length of scale bar is given in parentheses), A leaves $(2 \mathrm{~mm})$; B laminal cells near leaf apex $(200 \mu \mathrm{m})$; C mid leaf and marginal cells (margin to the right) $(200 \mu \mathrm{m}), \mathrm{D}$ basal and marginal cells (margin to the left) $(200 \mu \mathrm{m})$; E capsules, dry $(2 \mathrm{~mm})$. 
knotholes, whereas most European colonies reported in the literature were found on miscellaneous tree species, mainly Fagus sylvatica. In Hungary, previously 29 occurrences in 24 grid cells have been encountered, and there was only one occasion when A. splachnoides was found on more than one individual tree at a given site. With the recently found colonies reported here the number of grid cells in which $A$. splachnoides has been observed in Hungary is increased to 32. One of these new populations (Kopácsi Hill) with its relatively high total coverage on 19 different Turkey oak trees is of great significance not just from a regional point of view but also on a European scale.

Anacamptodon splachnoides is a rare and threatened species all across Europe. It is under legal protection in Hungary, and therefore its populations must be kept safe. In the case of Anacamptodon this must mean the protection not only of host trees where the species is already present, but also of those oak trees with hollows that might be considered potential habitats. In order to preserve the microclimate of a closed deciduous forest, very careful forest management strategies are proposed for the whole area of Kopácsi Hill with the application of selective cutting and the prevention of clear felling. As an initial practical conservation measure to preserve existing colonies of $A$. splachnoides on Kopácsi Hill, host trees were labelled by the Balaton Uplands National Park. In order to ensure long-term survival of the moss in the territory consultations were initiated with forestry management not to cut any oaks with knotholes at the growth site regardless of the presence or absence of the species on the individual trees.

Acknowledgements - We are grateful to Beáta Papp for granting access to the bryophyte database of the Department of Botany of the Hungarian Natural History Museum, to Attila Mesterházy, László Vókó, Erika Guba and Viktor Papp for participating in the field work, and to Ágnes Bezeczky and Charles Robin Stevenson for linguistic improvements. Many thanks are due to the reviewers for their useful comments on the manuscript.

Összefoglaló: Az Anacamptodon splachnoides egy különleges életmódú, fejlődésében bomló szerves anyaghoz, nitrogénben gazdag, organikus szubsztráthoz kötődő, nedvességigényes, ritka mohafaj. Ritkasága részben speciális, időben kevésbé stabil mikroélőhelyének tulajdonítható. Kis kiterjedésű gyepjei elsősorban és jellemzően csapadékvizes korhadéklével feltöltődött faüregek (dendrotelmák) falán és peremén, valamint nedves odúk, kéregrepedések környékén, a fatörzsek repedező, nedvedző, villás elágazásainál találhatók. Az elmúlt esztendők mohaflorisztikai kutatásai, kvadrát alapú mohatérképezése, illetve a faj célzott keresése során az A. splachnoides 27 kis populációja került elő a Magyar Középhegység területéről, minden esetben csertölgy (Quercus cerris) talajfelszín közeli, nedves odújából. Az előfordulások közül 3 a Börzsönyben, 2 a Vértesben, 2 a Gerecsében, 20 pedig a Balaton-felvidéken található. Utóbbiak közül a badacsonytomaji (Örsi-hegy) élőhely egyetlen faodújával földrajzilag elkülönül a szentbékkállai (Kopácsi-hegy) populációktól, ahol a faj kolóniái a bazaltplatón elterülő, lefolyástalan Füzes-tó környékének 20 hektáros sarjaztatott tölgyesében, 19 különböző faegyed üregében élnek. Az A. splachnoides Európa-szerte ritka és 
veszélyeztetett, Vörös Könyves faj, mely Magyarországon is törvényi oltalom alatt áll. Populációinak védelme a mohának otthont adó faegyedek védelme mellett a még nem kolonizált, de a megtelepedés szempontjából potenciálisnak tekinthető, odvas fák megóvását is kell, hogy jelentse. Továbbá a zárt lomberdei mikroklímaviszonyok megőrzése érdekében a faj élőhelyein a kíméletes, tarvágást kerülő, szálaló erdőművelés alkalmazása az irányadó.

\section{REFERENCES}

Ahrens, M. (2001): Fabroniaceae. - In: Nebel, M. and Philippi, G. (eds): Die Moose BadenWürttembergs 2. E. Ulmer, Stuttgart, pp. 242-245.

Amann, J. (1912): Flore des mousses de la Suisse, 2e partie. Bryogéographie de la Suisse. - Lausanne, $414 \mathrm{pp}$.

Anon. (2010): The Plant List. Version 1. Published on the Internet. - http://www.theplantlist.org/ (accessed 23.02.2015).

ANon. (2012): A vidékfejlesztési miniszter 100/2012. (IX. 28.) VM rendelete a védett és a fokozottan védett növény- és állatfajokról, a fokozottan védett barlangok köréről, valamint az Európai Közösségben természetvédelmi szempontból jelentős növény- és állatfajok közzétételéröl szóló 13/2001. (V. 9.) KöM rendelet és a növényvédelmi tevékenységről szóló 43/2010. (IV. 23.) FVM rendelet módosításáról [ministerial order concerning protection of nature]. - Magyar Közlöny 128: 20903-21019.

Atherton, I., Bosaneuet, S. and Lawley, M. (eds) (2010): Mosses and liverworts of Britain and Ireland: a field guide. - British Bryological Society, Plymouth, 848 pp.

Bednarek-Ochyra, H., Ochyra, R. and Szmajda, P. (1994): Anacamptodon splachnoides (Brid.) Brid. - In: Ochyra, R. and Szmajda, P. (eds): Atlas of the geographical distribution of spore plants in Poland, 9: 37-40. W. Szafer Institute of Botany, Polish Academy of Sciences and Adam Mickiewicz University, Kraków, Poznań.

Blockeel, T. L., Bosaneuet, S. D. S., Hill, M. O. and Preston, C. D. (eds) (2014): Atlas of British and Irish bryophytes, Vol. 2. - Pisces Publications, British Bryological Society, 652 pp.

Boros, Á. (1915-1971): Florisztikai jegyzetek. [Field diaries]. - Manuscript, Hungarian Natural History Museum, Budapest.

Boros, Á. (1968): Bryogeographie und Bryoflora Ungarns. - Akadémiai Kiadó, Budapest, 466 pp.

Breil, D. A. (2003): Common and occasional bryophytes of the Virginia Piedmont. - Banisteria 21: 3-27.

BRIDEL, A. (1819): Methodus nova muscorum ad naturae normam melius instituta et muscologiae recentiorum accomodata. - Ukertum, Gothae, $136 \mathrm{pp}$.

Crum, H. A. and Anderson, L. E. (1981): Mosses of Eastern North America. Vol. 1. - Columbia University Press, New York, 1328 pp.

Czernyadjeva, I. V. (2007): The genus Anacamptodon (Amblystegiaceae, Bryophyta) in Russia and Transcaucasia. - Arctoa 16: 1-6.

Davis, D. D. and Pursell, R. A. (2007): Collecting the Knot-Hole Moss (Anacamptodon splachnoides). - Evansia 24(1): 1-5.

DüLL, R. (1985): Distribution of the European and Macaronesian mosses (Bryophytina) II. Bryol. Beitr. 5: 110-232.

ECCB (1995): Red data book of European bryophytes. - European Committee for the Conservation of Bryophytes, Trondheim, $291 \mathrm{pp}$.

Frey, W., Frahm, J.-P., Fischer, E. and Lobin, W. (2006): The liverworts, mosses and ferns of Europe. - Harley Books, Colchester, 512 pp. 
GofFinet, B. and BUCK, R. (2004): Systematics of Bryophyta (Mosses): from molecules to a revised classification. - In: Goffinet, B., Hollowell, V. and MAGill, R. (eds): Molecular systematics of Bryophytes. Monogr. Syst. Bot. Missouri Bot. Garden 98: 150-167.

Grims, F. (1999): Die Laubmoose Österreichs. Catalogus Florae Austriae, Teil 2, Bryophyten (Moose), Heft 1, Musci (Laubmoose). - Biosyst. and Ecol. Ser. 15: 1-418.

Hill, M. O., Bell, N., Bruggemann-Nannenga, M. A., Brugues, M., Cano, M. J., Enroth, J., Flatberg, K. I., Frahm, J.-P., Gallego, M. T., Garilleti, R., Guerra, J., Hedenäs, L., Holyoak, D. T., Hyvönen, J., Ignatov, M. S., Lara, F., Mazimpaka, V., Muñoz, J. and SöDERSTRÖM, L. (2006): An annotated checklist of the mosses of Europe and Macaronesia. - J. Bryol. 28: 198-267. http://dx.doi.org/10.1179/174328206X119998

Kiebacher, T., BÜrgi, M., SCheIdegger, C. and Bergamini, A. (2012): Bryophyte diversity of sycamore pastures in the Northern Alps with a special emphasis on Tayloria rudolphiana. Abstracts, 8th Conference of the European Committee for Conservation of Bryophytes, Budapest, p. 13.

KuČera, J., VÁŇA, J. and Hradílek, Z. (2012): Bryophyte flora of the Czech Republic: updated checklist and Red List and a brief analysis. - Preslia 84: 813-850.

Ludwig, G., Düll, R., Philippi, G., Ahrens, M., Caspari, S., Koperski, M., Lütt, S., Schulz, F. and SchwaB, G. (1996): Rote Liste der Moose (Anthocerophyta et Bryophyta) Deutschlands. - In: Ludwig, G. and SchnitTler, M. (eds): Rote Liste gefährdeter Pflanzen Deutschlands. Schriftenr. f. Vegetationsk. 28: 189-306.

MAjesty , P. (2002): Anacamptodon. - Bryophyte flora of North America, Provisional publication, Buffalo Museum of Science, http://www.mobot.org/plantscience/bfna/V2/CampAnacamptodon.htm (accessed 26.01.2015).

Meinunger, L. and SCHRöDer, W. (2007): Verbreitungsatlas der Moose Deutschlands 2-3. - O. Dürhammer für die Regensburgische Botanische Gesellschaft, Regensburg.

PAPP, B. (2008): Selection of Important Bryophyte Areas in Hungary. - Folia Cryptog. Estonica 44: $101-111$.

PAPp, B. and ERzBerger, P. (2003): Data about the actual local populations of bryophyte species protected in Hungary. - Studia bot. bung. 34: 33-42.

PAPp, B., ErZberger, P., Ódor, P., Hock, Zs., SZÖVÉNYI, P., SZURdoki, E. and Tóth, Z. (2010): Updated checklist and red list of Hungarian bryophytes. - Studia bot. hung. 41: 31-59.

Pierrot, L. and Pierrot, B. (1975): Muscinées des Pyrénées centrales. - Monde Pl. 383: 4-7.

PLÁŠEK, V. (2012): New finding of noteworthy moss Anacamptodon splachnoides in the Moravskoslezské Beskydy Mts with summary of its recent occurrence in the Czech Republic. - Ćas. Slez. Muz. Opava (A) 61: 193-196.

Robert, V., STEgehuis, G. and STALPERs, J. (2005): The MycoBank engine and related databases. http://www.mycobank.org (accessed 23.02.2015).

SANDRon, L. and Hugonnot, V. (2012): The habitat of knothole moss Anacamptodon splachnoides in the Prats-de-Mollo-La Preste Protected Area (Pyrenées-Orientales, France). Polish Bot. J. 57(2): 317-326.

SCHNyder, N. (2011): Neufund von Anacamptodon splachnoides (Froel. ex Brid.) Brid. in der Schweiz. - Meylania 46: 24-27.

Schnyder, N., Bergamini, A., Hofmann, H., Müller, N., Schubiger-Bossard, C. and URMI, E. (2004): Rote Liste der gefährdeten Moose der Schweiz. - Hrsg. Buwal, Fub and Nism. Buwal-Reihe, Vollzug Umwelt, Bern, 99 pp.

SCHRÖDER, W. and MeINUnger, L. (1994): Über Neufunde von Anacamptodon splachnoides (Brid.) Brid. in Bayern. [Regarding new findings of Anacamptodon splachnoides (Brid.) Brid. in Bavaria]. - Herzogia 10: 133-136. 
SCHRÖDER, W. and MeINUNGER, L. (2000): Weitere Neufunde von Anacamptodon splachnoides (Brid.) Brid. in Bayern. - Limprichtia 14: 11-12.

ShARP, A.J. and ANDERSON, L. E. (1981): An unusual substrate for Knothole Moss, Anacamptodon splachnoides. - Bryologist 84(4): 539-542.

Simonkai L. (1879): Budapest környéke mohaflórája. [Die Moosflora der Umgebung von Budapest]. - Magyar Növénytani Lapok 3: 1-9.

Solberg, R. M. (1977): Hygrohypnum closteri new record and other noteworthy bryophytes in the Piedmont of North Carolina, USA. - Bryologist 80(1): 163-164.

ŞTEFĂnUȚ, S. and GoiA, I. (2012): Checklist and Red List of Bryophytes of Romania. - Nova Hedwigia 95: 59-104.

Szepesfalvi, J. (1938): Über das Vorkommen von Anacamptodon splachnoides (Fröl.) Brid. in Ungarn. - Borbásia 1: 15-16, 18-22.

(submitted: 29.01.2015, accepted 10.04.2015) 